\title{
Stimulatory Action of $\mathrm{Ba}^{2+}$ on Catecholamine Biosynthesis in Cultured Bovine Adrenal Chromaffin Cells: Possible Relation to Protein Kinase C
}

\author{
Kyoji MORITA, Kazuhiko TERAOKA, Mami AZUMA, \\ Motoo OKA and Shuichi HAMANO \\ Department of Pharmacology. Tokushima University School of Medicine. \\ Kuramoto, Tokushima 770, Japan
}

Accepted August 27, 1990

\begin{abstract}
The effect of $\mathrm{Ba}^{2+}$ on the catecholamine biosynthetic activity was studied by measuring the formation of $\left[{ }^{14} \mathrm{C}\right]$ catecholamines from $\mathrm{L}-\left[{ }^{14} \mathrm{C}\right]$ tyrosine in cultured adrenal chromaffin cells. In the absence of $\mathrm{Ca}^{2+},\left[{ }^{14} \mathrm{C}\right]$ catecholamine formation was markedly stimulated by $\mathrm{Ba}^{2+}$, and this stimulation was observed in a manner dependent on its concentration. The stimulation of $\left[{ }^{14} \mathrm{C}\right]$ catecholamine formation by relatively low concentrations of $\mathrm{Ba}^{2+}$ was suppressed by polymyxin $\mathrm{B}$, a typical inhibitor of $\mathrm{Ca}^{2+}$ /phospholipid-dependent protein kinase (protein kinase $\mathrm{C}$ ): and this inhibitory action of polymyxin $\mathrm{B}$ was attenuated by increasing the $\mathrm{Ba}^{2+}$ concentration. On the other hand, a tendency toward the enhancement of $\mathrm{Ba}^{2+}$ stimulated $\left[{ }^{14} \mathrm{C}\right]$ catecholamine formation was observed by a protein kinase $\mathrm{C}$ activator, 12-0-tetradecanoylphorbol 13-acetate (TPA). In contrast to the acute effect of TPA, $\left[{ }^{14} \mathrm{C}\right]$ catecholamine formation stimulated by $\mathrm{Ba}^{2+}$ was reduced by long-term exposure of chromaffin cells to a high concentration of TPA, which has already been reported to cause the reduction of protein kinase $C$ activity as a result of the down-regulation of this enzyme. These findings suggest that $\mathrm{Ba}^{2+}$ stimulates catecholamine biosynthesis, probably through its direct action on protein kinase $\mathrm{C}$ in adrenal chromaffin cells.
\end{abstract}

Catecholamine secretion evoked by cholinergic drugs or the depolarizing agents has already been established to be supported by the presence of extracellular $\mathrm{Ca}^{2+}(1,2)$. Recently, the essential role of $\mathrm{Ca}^{2+}$ in the intracellular secretory process has been confirmed using permeabilized chromaffin cells. which allows us to gain direct access to the cell interior (3-8). In contrast, $\mathrm{Ba}^{2+}$ has previously been reported to evoke catecholamine secretion without stimulating the plasma membranes, and the secretory action of $\mathrm{Ba}^{2+}$ has been shown to be independent of extracellular $\mathrm{Ca}^{2+}(9-12)$. The secretory action of $\mathrm{Ba}^{2+}$ was therefore considered to be mediated by a rise in the free $\mathrm{Ca}^{2+}$ concentration within the cells, resulting from displacing $\mathrm{Ca}^{2+}$ with $\mathrm{Ba}^{2+}$ from the intracellular store sites. On the other hand. $\mathrm{Ba}^{2+}$ has recently been found to stimulate the release of ATP concomitantly with that of catechol- amines from the adrenal chromaffin cell, and this stimulatory action has furthermore been shown to be mediated by the entry of $\mathrm{Ba}^{2+}$ into the cells, probably through voltage- and/ or receptor-gated $\mathrm{Ca}^{2+}$ channels. Thus, these results were considered to support the hypothesis that the intracellular events induced by stimulation of the cells with $\mathrm{Ba}^{2+}$ may in part coincide with those leading to the $\mathrm{Ca}^{2+}$ mediated exocytotic secretion (13). More recently, it has been proposed that $\mathrm{Ba}^{2+}$ can enter chromaffin cells through voltage-gated $\mathrm{Ca}^{2+}$ channels, and induces the stimulation of catecholamine secretion probably through its action on intracellular sites different from those affected by $\mathrm{Ca}^{2+}$ actions (14). Thus, the question of whether the intracellular sites of $\mathrm{Ba}^{2+}$ actions may be the same or different from those of $\mathrm{Ca}^{2+}$ actions has not yet been completely elucidated.

An earlier study demonstrated that $\mathrm{Ba}^{2+}$ - 
stimulated catecholamine secretion is accompained by stimulation of the phosphorylation of several proteins of the chromaffin cell. In particular, the $\mathrm{Ba}^{2+}$-stimulated phosphorylation of one of these proteins ( $95 \mathrm{~K}$ protein) has been found to be almost similar to that observed in the cells stimulated by nicotine (15). while previous studies on the direct actions of various divalent cations on exocytotic secretion and protein kinase $\mathrm{C}$ activity have shown that $\mathrm{Ba}^{2+}$ may be able to substitute for $\mathrm{Ca}^{2+}$ in the activation of protein kinase $\mathrm{C}$ as well as the stimulation of catecholamine release from electrically permeabilized chromaffin cells (16). It thus seems reasonable to conclude that $\mathrm{Ba}^{2+}$ may induce catecholamine secretion as a consequence of stimulating the $\mathrm{Ca}^{2+}$-activated secretory mechanism, probably through its direct action on protein kinase $\mathrm{C}$ in adrenal chromaffin cells. Generally. the stimulation of catecholamine secretion by various secretagogues is known to be accompanied by an elevation in the ability of catecholamine biosynthesis in various adrenergic tissues (17). On the other hand, it has been established that tyrosine hydroxylase. which is the rate-limiting enzyme in the catecholamine biosynthetic pathway, is activated by phosphorylation of the enzyme protein catalyzed by various protein kinases including protein kinase $C$ (1826). Furthermore, $\mathrm{Ba}^{2+}$ has been reported to stimulate the phosphorylation of tyrosine hydroxylase accompanied by the activation of this enzyme (27). In view of these findings, it therefore seems reasonable to presume that $\mathrm{Ba}^{2+}$ may be able to stimulate catecholamine biosynthesis through the activation of protein kinases within the cell. In the present study, we then examined the effect of $\mathrm{Ba}^{2+}$ on catecholamine biosynthesis by measuring the formation of $\left[{ }^{14} \mathrm{C}\right]$ catecholamines from $\left[{ }^{14} \mathrm{C}\right]$ tyrosine in cultured bovine adrenal chromaffin cells. The possibility that the effect of $\mathrm{Ba}^{2+}$ on catecholamine biosynthesis may be mediated by protein kinase $C$ was also verified using agents that modulate the activity of this enzyme.

\section{Materials and Methods}

Cell preparation and culture: Chromaffin cells were enzymatically prepared from fresh bovine adrenal medulla according to the previously reported method (28). Isolated cells were plated on 24-well plastic cluster plates at a density of $5 \times 10^{5}$ cells/well, and maintained for 3 or 4 days as monolayer cultures at $37^{\circ} \mathrm{C}$ in a humidified atmosphere containing $5 \% \mathrm{CO}_{2}$ in $1.5 \mathrm{ml}$ of Eagle's minimum essential medium containing $5 \%$ heat-inactivated newborn calf serum, $2 \mathrm{mM}$ glutamine, $100 \mathrm{U} / \mathrm{ml}$ of penicillin, $100 \mu \mathrm{g} / \mathrm{ml}$ of streptomycin, 50 $\mu \mathrm{g} / \mathrm{ml}$ of gentamicin, $2 \mu \mathrm{g} / \mathrm{ml}$ of fungizone. and $10 \mu \mathrm{M}$ cytosine arabinoside.

Determination of $\left[{ }^{14} \mathrm{C}\right]$ catecholamine formation: Cells were washed with $1 \mathrm{ml}$ of balanced salt solution $[135 \mathrm{mM} \mathrm{NaCl}, 5.6 \mathrm{mM}$ $\mathrm{KCl}, 1.2 \mathrm{mM} \mathrm{MgCl}, 2.2 \mathrm{mM} \mathrm{CaCl}_{2}, 10 \mathrm{mM}$ glucose, and $20 \mathrm{mM}$ 4-(2-hydroxyethyl)-1piperazineethanesulfonic acid (HEPES), $\mathrm{pH}$ 7.35], and incubated with $20 \mu \mathrm{M} \mathrm{L}-\left[{ }^{14} \mathrm{C}\right]$ tyrosine $(0.25 \mu \mathrm{Ci})$ at $37^{\circ} \mathrm{C}$ for $30 \mathrm{~min}$ in 500 $\mu l$ of $\mathrm{Ba}^{2+}$-containing balanced salt solution in which $\mathrm{CaCl}_{2}$ was substituted by various concentrations of $\mathrm{BaCl}_{2}$. At the end of the incubation period, the medium was discarded by aspiration, and the cells were washed twice with $1 \mathrm{ml}$ of ice-cold balanced salt solution on ice, and then lysed by adding $500 \mu \mathrm{l}$ of $0.4 \mathrm{M}$ perchloric acid and subjecting them to a freeze-thaw cycle. The cell lysates were centrifuged at $9,000 \times \mathrm{g}$ for $5 \mathrm{~min}$, and radioactivity in an aliquot $(50 \mu l)$ of the supernatant fraction was counted by a liquid scintillation spectrometer to measure the amount of $\left[{ }^{14} \mathrm{C}\right]$ tyrosine taken up into the cells. Radioactive catecholamines contained in the acid extracts $(400 \mu l)$ were isolated onto aluminum hydroxide gel, and radioactivity eluted from the gel was then determined by liquid scintillation spectrometry (29). $\mathrm{Ba}^{2+}$-induced $\left[{ }^{14} \mathrm{C}\right]$ catecholamine formation was calculated by subtracting the values obtained in the absence of $\mathrm{Ba}^{2+}$ from those obtained in the presence of $\mathrm{Ba}^{2+}$ in the reaction mixture.

Statistical analysis: Standard deviation (S.D.) of the difference between two groups was calculated as $\left(\mathrm{SD}_{1}^{2}+\mathrm{SD}_{2}^{2}\right)^{1 / 2}$, and Student's $t$-test was used to determine statistical significance.

Chemicals: L- $\left[U-{ }^{14} \mathrm{C}\right]$ tyrosine was purchased from Amersham Japan Corp. (Tokyo, Japan). Polymyxin B. TPA, and carbamylcho- 
line were obtained from Sigma Chemical Co. (St. Louis, MO, U.S.A.). Other chemicals used were of commercially available reagent grades.

\section{Results}

Effect of $\mathrm{Ba}^{2+}$ on catecholamine biosynthesis in cultured adrenal chromaffin cells: To examine the effect of $\mathrm{Ba}^{2+}$ on the activity of catecholamine biosynthesis in cultured adrenal chromaffin cells, $\left[{ }^{14} \mathrm{C}\right]$ catecholamine formation from $\mathrm{L}-\left[{ }^{14} \mathrm{C}\right]$ tyrosine in the cells stimulated with $\mathrm{Ba}^{2+}$ was first determined. As shown in Fig. 1. [ $\left.{ }^{14} \mathrm{C}\right]$ catecholamine formation was observed as a function of the incubation time, and the accumulation of $\left[{ }^{4} \mathrm{C}\right]$ catecholamines within the cells reached almost the plateau level after a 45 -min incubation in the absence of $\mathrm{Ba}^{2+}$. Under these conditions, the formation of $\left[{ }^{14} \mathrm{C}\right]$ catecholamines was markedly enhanced by $\mathrm{Ba}^{2+}$, and this enhancement was observed even at a 60 min incubation. In general, since it is prerequisite for $\left[{ }^{14} \mathrm{C}\right]$ catecholamine formation that the precursor pools within the cells are label-

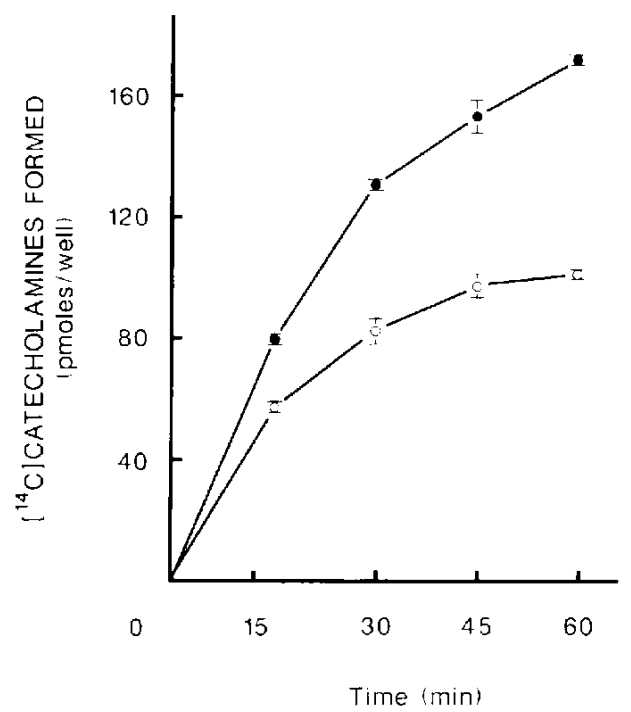

Fig. 1. Catecholamine biosynthesis as a function of the incubation time. Cells were incubated with 20 $\mu \mathrm{M} \mathrm{L}-\left[{ }^{14} \mathrm{C}\right]$ tyrosine $(0.25 \mu \mathrm{Ci} /$ well $)$ at $37^{\circ} \mathrm{C}$ for different time periods in the presence (O) and absence (O) of $2 \mathrm{mM} \mathrm{BaCl}_{2}$. The amount of $\left[{ }^{14} \mathrm{C}\right]-$ catecholamines within the cells was determined as described in the text. Values are the mean $\pm S$.D. $(n=3)$. led with $L-\left[{ }^{14} C\right]$ tyrosine, a lag of the increase in $\left[{ }^{14} \mathrm{C}\right]$ catecholamine formation is usually observed at the beginning of the incubation. while because newly formed $\left[{ }^{14} \mathrm{C}\right]$ catecholamines are thought to be released by stimulation of the cells with $\mathrm{Ba}^{2+}$, an increase in the amount of $\left[{ }^{14} \mathrm{C}\right]$ catecholamines within the cells tends to level off after a long-time incubation. Thus, to properly evaluate the effect of $\mathrm{Ba}^{2+}$ on the catecholamine biosynthetic activity, it is important to choose an appropriate incubation time. Under the conditions used here, the $\mathrm{Ba}^{2+}$-stimulated fraction of $\left[{ }^{14} \mathrm{C}\right]$ catecholamine formation was shown to be well-correlated to the incubation time from 15 to $60 \mathrm{~min}$ (Fig. 2). In our subsequent experiments, a 30 min incubation was therefore employed to determine the stimulatory action of $\mathrm{Ba}^{2+}$ on the formation of $\left[{ }^{14} \mathrm{C}\right]$ catecholamines in adrenal chromaffin cells.

The stimulatory action of $\mathrm{Ba}^{2+}$ on $\left[{ }^{14} \mathrm{C}\right]$ catecholamine formation was also observed as a function of its concentration. As shown in Fig. 3, a substantial increase in $\mathrm{Ba}^{2+}$ induced $\left[{ }^{14} \mathrm{C}\right]$ catecholamine formation was

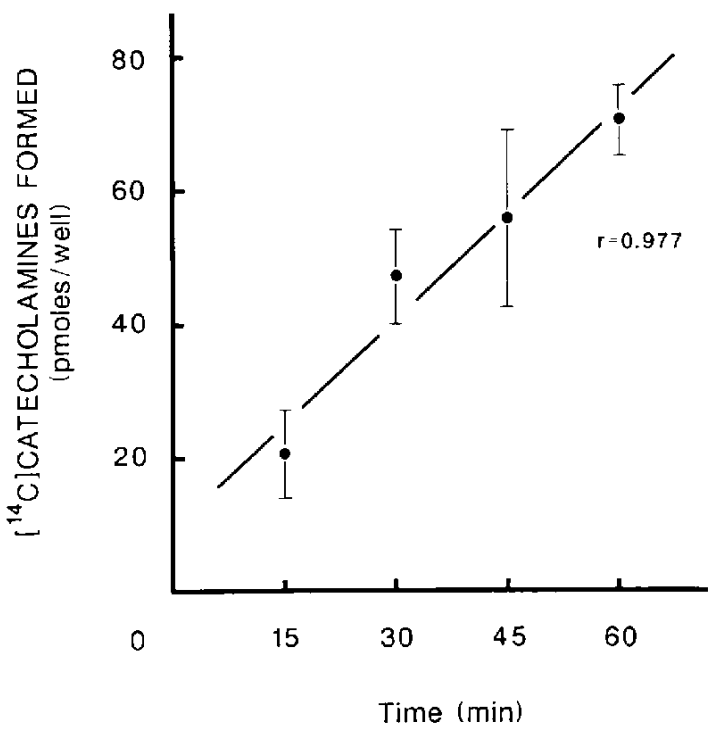

Fig. 2. Correlation between $\mathrm{Ba}^{2+}$-stimulated catecholamine biosynthesis and the incubation time. The $\mathrm{Ba}^{2+}$-stimulated fraction of $\left[{ }^{14} \mathrm{C}\right]$ catecholamine formation was obtained as the difference between the basal and the $\mathrm{Ba}^{2+}$-stimulated values presented in Fig. 1. and then plotted against the incubation time. The line in the figure was obtained by linearregression analysis. Values are the mean \pm S.D. 
observed at $0.1 \mathrm{mM} \mathrm{Ba}^{2+}$, and it reached almost the maximum level at $2 \mathrm{mM}$. This increase in $\left[{ }^{14} \mathrm{C}\right]$ catecholamine formation was not enhanced any further by increasing the $\mathrm{Ba}^{2+}$ concentration up to $4 \mathrm{mM}$ (data not included in Fig. 3). In contrast, the uptake of $\left[{ }^{14} \mathrm{C}\right]$ tyrosine into the cells was not affected by $\mathrm{Ba}^{2+}$ at any concentrations tested here (data not shown).

Effects of protein kinase $C$ modulators on $\mathrm{Ba}^{2+}$-induced catecholamine biosynthesis in cultured adrenal chromaffin cells: To test the possibility that the stimulatory action of $\mathrm{Ba}^{2+}$ on catecholamine biosynthesis is probably mediated by protein kinase $C$, the effect of the protein kinase $\mathrm{C}$ inhibitor polymyxin $\mathrm{B}$ on $\mathrm{Ba}^{2+}$-stimulated $\left[{ }^{14} \mathrm{C}\right]$ catecholamine formation was examined. As shown in Fig. 4, $\left[{ }^{14} \mathrm{C}\right]$ catecholamine formation stimulated by relatively low concentrations of $\mathrm{Ba}^{2+}$ was markedly inhibited by polymyxin B (400 units/ml). and this inhibitory action was attenuated by elevating the $\mathrm{Ba}^{2+}$ concentration in the incubation mixture. The significant effect of polymyxin $B$ on $\left[{ }^{14} \mathrm{C}\right]$ catecholamine formation was no longer observed when the cells were stimulated by $1 \mathrm{mM} \mathrm{Ba}^{2+}$, and the in-

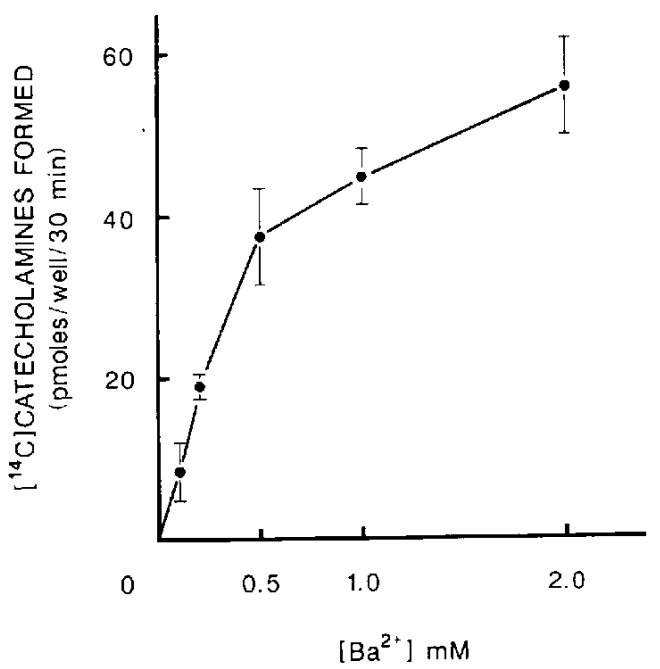

Fig. 3. Effect of various concentrations of $\mathrm{Ba}^{2+}$ on catecholamine biosynthesis. Cells were incubated with various concentrations of $\mathrm{BaCl}_{2}$ at $37^{\circ} \mathrm{C}$ for $30 \mathrm{~min}$ in the presence of $\mathrm{L}-\left[{ }^{14} \mathrm{C}\right]$ tyrosine, and the amount of $\left[{ }^{14} \mathrm{C}\right]$ catecholamines was determined as described in the text. Values are the mean \pm S.D. $(n=3)$. hibitory action of this drug almost completely disappeared in the presence of $\mathrm{Ba}^{2+}$ at concentrations higher than $2 \mathrm{mM}$ (data not included in Fig. 4). The effect of TPA, which is known as an activator of protein kinase $C$, on $\left[{ }^{14} \mathrm{C}\right]$ catecholamine formation was studied in the presence of lower concentrations of $\mathrm{Ba}^{2+}$. TPA itself caused no significant influence on the basal level of $\left[{ }^{14} \mathrm{C}\right]$ catecholamine formation, but this compound was shown to have a tendency to enhance the effect of a low concentration of $\mathrm{Ba}^{2+}$ on $\left[{ }^{14} \mathrm{C}\right]$ catecholamine formation under the experimental conditions used here (Fig. 5).

To confirm the possibility that the stimulatory action of $\mathrm{Ba}^{2+}$ on catecholamine biosynthesis may be related to the activation of protein kinase $C$, the cells were cultured for 24 $h r$ in the medium containing $1 \mu \mathrm{M} \mathrm{TPA}$, and the effect of $\mathrm{Ba}^{2+}$ on $\left[{ }^{14} \mathrm{C}\right]$ catecholamine formation was then determined in these cells. As shown in Fig. 6, the prolonged exposure of the

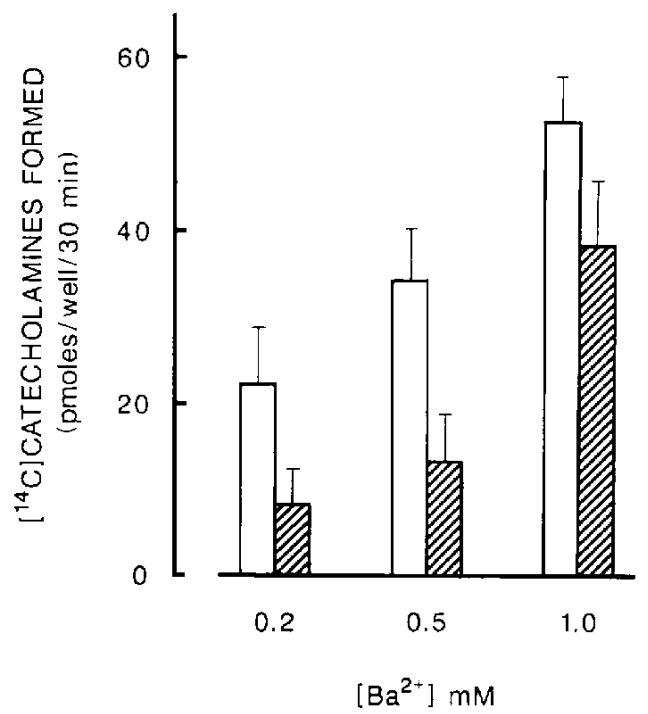

Fig. 4. Inhibition of $\mathrm{Ba}^{2+}$-stimulated catecholamine biosynthesis by polymyxin $\mathrm{B}$. Cells were incubated with $\mathrm{L}-\left[{ }^{14} \mathrm{C}\right]$ tyrosine at $37^{\circ} \mathrm{C}$ for $30 \mathrm{~min}$ in the mixture containing different concentrations of $\mathrm{BaCl}_{2}$ with (hatched column) or without (open column) 400 units $/ \mathrm{ml}$ of polymyxin $\mathrm{B}$. The amount of $\left[{ }^{14} \mathrm{C}\right]$ catecholamines was determined as described in the text. Values are the mean \pm S.D. $(n=3)$. Statistically significant differences between two groups were observed at 0.2 and $0.5 \mathrm{mM}$, but not at $1 \mathrm{mM} \mathrm{Ba}^{2+}$ $(P<0.025)$. 


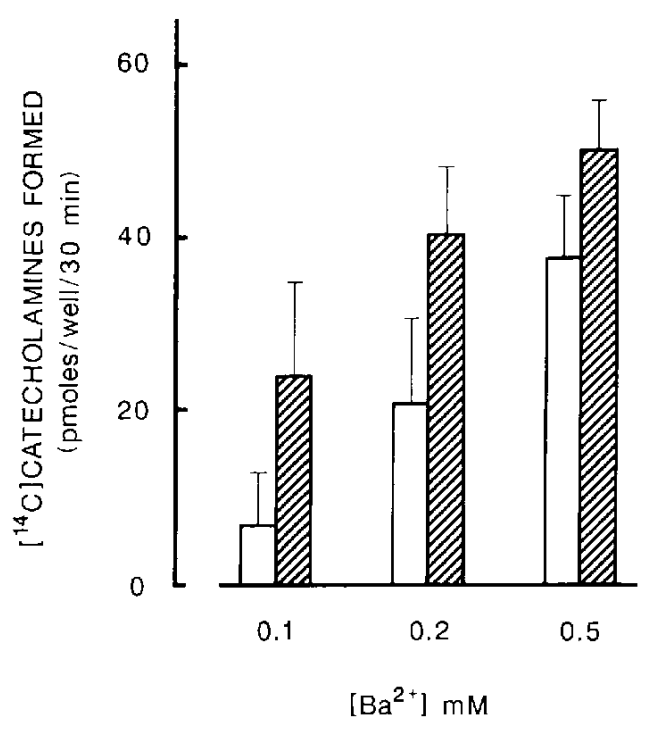

Fig. 5. Effect of phorbol ester TPA on $\mathrm{Ba}^{2+}$ stimulated catecholamine biosynthesis. Cells were incubated with L- $\left[{ }^{14} \mathrm{C}\right]$ tyrosine at $37^{\circ} \mathrm{C}$ for $30 \mathrm{~min}$ in the mixture containing low concentrations of $\mathrm{BaCl}_{2}$ with (hatched column) or without (open column) $100 \mathrm{nM}$ TPA. The amount of $\left[{ }^{14} \mathrm{C}\right]$ catecholamines was determined as described in the text. Values are the mean+S.D. $(n=3)$. The difference between two groups was not statistically significant $(P<0.025)$.

cells to TPA resulted in a decrease in $\left[{ }^{14} \mathrm{C}\right]$ catecholamine formation evoked by carbamylcholine or high $\mathrm{K}^{+}$. Similarly, the stimulation of $\left[{ }^{14} \mathrm{C}\right]$ catecholamine formation by $\mathrm{Ba}^{2+}$ was also reduced by the long-term exposure to TPA. Thus, the chronic exposure of the cells to relatively high concentration of TPA was shown to cause the reduction of the stimulatory action of $\mathrm{Ba}^{2+}$ on catecholamine biosynthesis in adrenal chromaffin cells.

\section{Discussion}

In the present study, $\mathrm{Ba}^{2+}$ was found to stimulate dramatically the formation of $\left[{ }^{14} \mathrm{C}\right]$ catecholamines in cultured chromaffin cells without any significant alteration in the uptake of $\left[{ }^{14} \mathrm{C}\right]$ tyrosine into the cells, and this effect was also shown to be dependent on the $\mathrm{Ba}^{2+}$ concentration in the incubation mixture (Figs. 1 and 3 ). The dose-response curve of $\left[{ }^{14} \mathrm{C}\right]$ catecholamine formation obtained here was almost similar to that of catecholamine secretion stimulated by $\mathrm{Ba}^{2+}$ from cultured adrenal

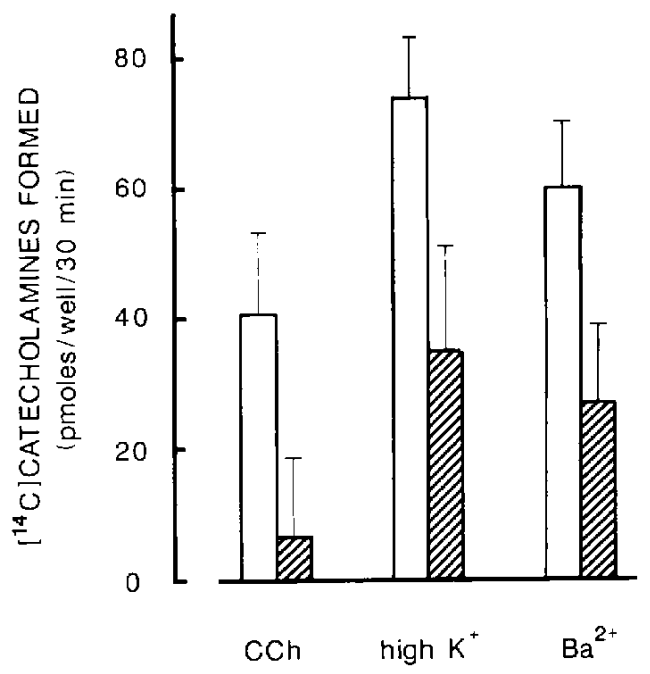

Fig. 6. Chronic effect of phorbol ester TPA on catecholamine biosynthesis stimulated by differenttype secretagogues. Cells were pretreated with (hatched column) or without (open column) 1.0 " M TPA for $24 \mathrm{hr}$ in the culture medium and then stimulated by $56 \mathrm{mM} \mathrm{KCl}, 300 \mu \mathrm{M}$ carbamylcholine. or $2 \mathrm{mM} \mathrm{BaCl}$ at $37^{\circ} \mathrm{C}$ for $30 \mathrm{~min}$ in the mixture containing $\mathrm{L}-\left[{ }^{14} \mathrm{C}\right]$ tyrosine. The amount of $\left[{ }^{14} \mathrm{C}\right]-$ catecholamines was then determined as described in the text. Values are the mean 1 S.D. $(n=3)$. The statistically significant difference between two groups was observed in all three cases $(P<0.025)$.

chromaffin cells ( $K$. Morita et al., unpublished data). In addition to the stimulatory action of $\mathrm{Ba}^{2+}$ on catecholamine secretion reported previously $(9-12), \mathrm{Ba}^{2+}$ is clearly shown here to stimulate catecholamine biosynthesis in adrenal medullary cells.

The stimulation of $\left[{ }^{14} \mathrm{C}\right]$ catecholamine formation induced by low concentrations of $\mathrm{Ba}^{2+}$ was shown to be significantly inhibited by the protein kinase $\mathrm{C}$ inhibitor polymyxin $\mathrm{B}$, and this inhibitory action seemed to be overcome by elevating the $\mathrm{Ba}^{2+}$ concentration in the incubation mixture (Fig. 4). It has already been established that phosphatidylserine causes the activation of protein kinase $C$ as a result of increasing the affinity of the enzyme for $\mathrm{Ca}^{2+}$. On the other hand, since polymyxin $B$ has already been shown to inhibit more specifically protein kinase C competitively with respect to phosphatidylserine $(30)$, it seems conceivable that polymyxin B may indirectly decrease the affinity of protein 
kinase $\mathrm{C}$ for $\mathrm{Ca}^{2+}$ through its blocking action on the effect of phospholipid cofactor. In view of these findings, the stimulatory action of $\mathrm{Ba}^{2+}$ on catecholamine biosynthesis seems to be mediated by the activation of protein kinase $C$. Furthermore, the finding that the inhibitory action of polymyxin $\mathrm{B}$ on $\mathrm{Ba}^{2+}$ stimulated catecholamine biosynthesis was overcome by elevating the $\mathrm{Ba}^{2+}$ concentration is therefore considered to indicate that polymyxin $\mathrm{B}$ may act on the site(s) of $\mathrm{Ba}^{2+}$ action, and then causes a decrease in the affinity for $\mathrm{Ba}^{2+}$, similar to the decrease in the affinity of protein kinase $\mathrm{C}$ for $\mathrm{Ca}^{2+}$. It seems possible to presume that the site related to the inhibitory action of polymyxin B on the $\mathrm{Ba}^{2+}$ action is probably the same as that involved in its inhibitory action on the $\mathrm{Ca}^{2+}$ action, and the site commonly related to both the $\mathrm{Ba}^{2+}$ and $\mathrm{Ca}^{2+}$ actions is supposed to be protein kinase $\mathrm{C}$. If this idea is correct, it seems reasonable to consider that the stimulation of catecholamine biosynthesis by $\mathrm{Ba}^{2+}$ is enhanced by TPA, a protein kinase $C$ activator. In fact, a tendency to enhance $\mathrm{Ba}^{2+}$ stimulated $\left[{ }^{14} \mathrm{C}\right]$ catecholamine formation was observed by adding TPA to the incubation mixture (Fig. 5).

In view of the earlier findings that the prolonged exposure to relatively high concentrations of TPA causes the reduction of the amount of protein kinase $C$ as a result of down-regulation of this enzyme in several cell types (31-34) including adrenal chromaffin cells (35), the chronic treatment of the cells with TPA therefore seemed to be the most suitable way to confirm the possible involvement of protein kinase $C$ in the cell function. Catecholamine biosynthesis stimulated by carbamylcholine or high $\mathrm{K}^{+}$, which is wellestablished to be mediated by $\mathrm{Ca}^{2+}$-activated protein kinases, was shown to be markedly reduced by the exposure of the cells to TPA. It therefore seems conceivable that the decrease in catecholamine biosynthesis observed here may directly reflect a decrease in the amount of protein kinase $C$. In addition. the substantial decrease in $\mathrm{Ba}^{2+}$-stimulated catecholamine biosynthesis was observed in the cells pretreated with TPA under the conditions in which the down-regulation of protein kinase $\mathrm{C}$ might occur (Fig. 6 ). It there- fore seems likely that the stimulatory action of $\mathrm{Ba}^{2+}$ on catecholamine biosynthesis may be mediated by the stimulation of protein kinase $C$ activity in the adrenal chromaffin cell.

Although the present study suggests that $\mathrm{Ba}^{2+}$ may stimulate the $\mathrm{Ca}^{2+}$-dependent cell functions as a consequence of the stimulation of protein phosphorylation mediated by protein kinase $C$, it seems still questionable whether $\mathrm{Ba}^{2+}$ may be able to stimulate directly the $\mathrm{Ca}^{2+}$-dependent mechanism or stimulate indirectly this process through displacing $\mathrm{Ca}^{2+}$ from the intracellular store sites, since a previous study has shown that $\mathrm{Ba}^{2+}$ can substitute for $\mathrm{Ca}^{2+}$ in the activation of protein kinase $C$ in vitro (16). Furthermore, because it has been reported that $\mathrm{Ba}^{2+}$ can induce the activation of tyrosine hydroxylase as a result of stimulating the enzyme phosphorylation within the cells (27), it therefore seems likely that $\mathrm{Ba}^{2+}$ may directly activate protein kinase $\mathrm{C}$. leading to the activation of tyrosine hydroxylase through the phosphorylation of the enzyme itself, thus resulting in the stimulation of catecholamine biosynthesis in the adrenal chromaffin cell.

Acknowledgments: This work was supported in part by grants from the Japanese Ministry of Education. Science and Culture.

\section{References}

1 Douglas, W.W.: Stimulus-secretion coupling: the concept and clues from chromaffin and other cells. Br. J. Pharmacol. Chemother, 34, 451--474 (1968)

2 Viveros, O.H.: Mechanism of secretion of catecholamines from adrenal medulla. In Handbook of Physiology and Endocrinology. Edited by Blaschko, H., Sayers, G. arid Smith, A.D., p. 389-426, American Physiological Society. Washington, D.C. (1975)

3 Baker, P.F. and Knight, D.E.: Calcium control of exocytosis and endocytosis in bovine adrenal medullary cells. Philos. Trans. R. Soc. Lond. [Biol.] 296, 83-103 (1981)

4 Knight, D.E. and Baker, P.F.: Calcium-dependence of catecholamine release from bovine adrenal medullary cells after exposure to intense electric fields. J. Membr. Biol. 68, 107-140 (1982)

5 Dunn, L.A. and Holz, R.W.: Catecholamine secretion from digitonin-treated adrenal medullary chromaffin cells. J. Biol. Chem. 258, 4989- 
4993 (1983)

6 Wilson, S.P. and Kirshner. N.: Calcium-evoked secretion from digitonin-permeabilized adrenal medullary chromaffin cells. J. Biol. Chem. 258, 4994-5000 (1983)

7 Brooks, J.C. and Treml, S.: Catecholamine secretion by chemically skinned cultured chromaffin cells. J. Neurochem. 40, 468-473 (1983)

8 Ahnert-Hilger, G., Bhakdi, S. and Gratzl, M.: Minimal requirements for exocytosis: a study using PC12 cells permeabilized with staphylococcal a-toxin. J. Biol. Chem. 260, 1273012734 (1985)

9 Douglas, W.W. and Rubin, R.P.: Stimulant action of barium on the adrenal medulla. Nature 203, 305-307 (1964)

10 Douglas, W.W. and Rubin, R.P.: The effects of alkaline earths and other divalent cations on adrenal medullary secretion. J. Physiol. (Lond.) 175, 231-241 (1964)

11 Douglas, W.W. and Poisner, A.M.: On the relation between ATP splitting and secretion in the adrenal medulla: Extrusion of ATP (unhydrolysed) during release of catecholamines. J. Physiol. (Lond.) 183, 249-256 (1966)

12 Corcoran, J.J. and Kirshner, N.: Effects of manganese and other divalent cations on calcium uptake and catecholamine secretion by primary cultures of bovine adrenal medulla cells. Cell Calcium 4, 127-137 (1983)

13 Forsberg, E.J. and Pollard, H.B.: $\mathrm{Ba}^{2+}$-induced ATP release from adrenal medullary chromaffin cells is mediated by $\mathrm{Ba}^{2+}$ entry through both voltage- and receptor-gated $\mathrm{Ca}^{2+}$ channels. Neuroscience 27, 711-715 (1988)

14 Heldman, E., Levine, M., Raveh, L. and Pollard, H.B.: Barium ions enter chromaffin cells via voltage-dependent calcium channels and induce secretion by a mechanism independent of calcium. J. Biol. Chem. 264, 7914-7920 (1989)

15 Amy, C.M. and Kirshner, N.: Phosphorylation of adrenal medulla cell proteins in conjunction with stimulation of catecholamine secretion. J. Neurochem. 36, 847-854 (1981)

16 Knight, D.E., Sugden, D. and Baker, P.F.: Evidence implicating protein kinase $C$ in exocytosis from electropermeabilized bovine chromaffin cells. J. Membr. Biol. 104, 21-34 (1988)

17 Ungar, A. and Phillips, J.H.: Regulation of the adrenal medulla. Physiol. Rev. 63, 787-843 (1983)

18 Joh, T.H., Park, D.H. and Reis, D.J.: Direct phosphorylation of brain tyrosine hydroxylase by cyclic AMP-dependent protein kinase:
Mechanism of enzyme activation. Proc. Natl. Acad. Sci. U.S.A. 75, 4744-4748 (1978)

19 Yamauchi, T. and Fujisawa, H.: In vitro phosphorylation of bovine adrenal tyrosine hydroxylase by adenosine $3^{\prime}: 5^{\prime}$-monophosphate-dependent protein kinase. J. Biol. Chem. 254, 503-507 (1979)

20 Vulliet, P.R., Langan, T.A. and Weiner, N.: Tyrosine hydroxylase: a substrate of cyclic AMPdependent protein kinase. Proc. Natl. Acad. Sci. U.S.A. 77, 92-96 (1980)

21 Vulliet, P.R., Woodgett, J.R. and Cohen, P.: Phosphorylation of tyrosine hydroxylase by calmodulin-dependent multiprotein kinase. J. Biol. Chem. 259, 13680-13683 (1984)

22 Albert, K.A., Helmer-Matyjek, E., Nairn, A.C., Müller, T.H., Haycock, J.W., Greene, L.A., Goldstein, M. and Greengard, P.: Calcium/phospholipid-dependent protein kinase (protein kinase C) phosphorylates and activates tyrosine hydroxylase. Proc. Natl. Acad. Sci. U.S.A. 81, 7713-7717 (1984)

23 Vulliet, P.R., Woodgett, J.R., Ferrari, S. and Hardie, D.G.: Characterization of the sites phosphorylated on tyrosine hydroxylase by $\mathrm{Ca}^{2+}$ and phospholipid-dependent protein kinase, calmodulin-dependent multiprotein kinase and cyclic AMP-dependent protein kinase. FEBS Lett. 182, 335-339 (1985)

24 Roskoski, R., Jr., Vulliet, P.R. and Glass, D.B.: Phosphorylation of tyrosine hydroxylase by cyclic GMP-dependent protein kinase. J. Neurochem. 48, 840-845 (1987)

25 Rowland, E.A., Müller, T.H., Goldstein, M. and Greene, L.A.: Cell-free detection and characterization of a novel nerve growth factor-activated protein kinase in PC12 cells. J. Biol. Chem. 262, 7504-7513 (1987)

26 George, R.J., Haycock, J.W., Johnston, J.P., Craviso, G.L. and Waymire, J.C.: In vitro phosphorylation of bovine adrenal chromaffin cell tyrosine hydroxylase by endogenous protein kinases. J. Neurochem. 52, 274-284 (1989)

27 Pocotte, S.L., Holz, R.W. and Ueda, T.: Cholinergic receptor-mediated phosphorylation and activation of tyrosine hydroxylase in cultured bovine adrenal chromaffin cells. J. Neurochem. 46, 610-622 (1986)

28 Morita, K., Ishii, S., Uda, H. and Oka, M.: Requirement of ATP for exocytotic release of catecholamines from digitonin-permeabilized adrenal chromaffin cel!s. J. Neurochem. 50, 644648 (1988)

29 Levine, M., Morita, K. and Pollard, H.B.: Enhancement of norepinephrine biosynthesis by ascorbic 
acid in cultured bovine chromaffin cells. J. Biol. Chem. 260, 12942-12947 (1985)

30 Mazzei, G.J., Katoh, N. and Kuo, J.F.: Polymyxin $B$ is a more selective inhibitor for phospholipid-sensitive $\mathrm{Ca}^{2+}$-dependent protein kinase than for calmodulin-sensitive $\mathrm{Ca}^{2+}$ dependent protein kinase. Biochem. Biophys. Res. Commun. 109, 1129-1133 (1982)

31 Rodriguez-Pena, $A$. and Rozengurt, E.: Disappearance of $\mathrm{Ca}^{2+}$-sensitive. phospholipid-dependent protein kinase activity in phorbol estertreated $3 T 3$ cells. Biochem. Biophys. Res. Commun. 120, 1053-1059 (1984)

32 Ballester, R. and Rosen, O.M.: Fate of immunoprecipitable protein kinase $\mathrm{C}$ in $\mathrm{GH} 3$ cells treated with phorbol 12-myristate 13-acetate. J. Biol. Chem. 260, 15194-15199 (1985)

33 Matthies, H.J., Palfrey, H.C., Hirning, L.D. and Miller, R.J.: Down regulation of protein kinase $C$ in neuronal cells: effects on neurotransmitter release. J. Neurosci. 7, 1198-1206 (1987)

34 Grove, D.S. and Mastro, A.M.: Prevention of the TPA-mediated down-regulation of protein kinase $C$. Biochem. Biophys. Res. Commun. 151, 94-99 (1988)

35 Wilson, S.P.: Regulation of chromaffin cell secretion and protein kinase $C$ activity by chronic phorbol ester treatment. J. Biol. Chem. 265, 648-651 (1990) 